\title{
RESPONSIBILITY OF PUBLIC HEALTH SERVICE BASED ON THE CONSTITUTION OF INDONESIA
}

\author{
Ardiansah \\ Faculty of Law, Lancang Kuning University \\ ardiansah@unilak.ac.id
}

\begin{abstract}
The Indonesian Constitution has mandated health services for its people. Everyone has the right to receive health services, while the state is obliged to provide health services. The implementation of public health services faces problems concerning the president regulations about the increase of health insurance fee. The House of Representatives does not agree with the increase in health insurance fee, because the government should be responsible for the realization of public health services. This research uses normative legal research methods. The results showed that the government's policy of raising fees was considered unfair and burdensome to the people of Indonesia. Health services for the people of Indonesia has been mandated by The Indonesian Constitution. The denial of health services is a violation to the Indonesian constitution. The people have the right to get health services, whereas the state is responsible for providing health services. Therefore, even though the government raises fees, people expect the government to cancel the increase of the fee. Due to the fact that the Indonesian constitution has made it clear that the state is responsible for providing health services to its people.
\end{abstract}

Keywords: Responsibility; Health Service; Indonesian Constitution

\section{Introduction}

President Joko Widodo has issued Presidential Regulation Number 75 of 2019 concerning Amendment to Presidential Regulation Number 82 of 2018 regarding Health Insurance. This Presidential Regulation officially increases the fee rates by 100 percent to the Health - Social Security Institution for Non-Wage and Non-Worker participants. The President asked the public to understand this regulation (about the increase of the fee rates). According to the president, this regulation was not to burden the poor. During this time, the government has spent tens of trillions rupiah to help the poor for their healthcare. ${ }^{1}$

The House of Representatives did not agree with the issuance of this Presidential Regulation. One of parliament member, Kurniasih Mufidayati was disappointed with the increase of the fee of the Health - Social Security Institution. According to Kurniasih, the increase that applied to all classes and classifications of participants without exception was quite burdensome for the independent participants. Kurniasih was disappointed because the Government ignored the agreed decision made by the parliament. The Government and the

1 Iuran BPJS Kesehatan Naik 1000 Persen, Jokowi Minta rakyat Mengerti, 31 Oktober 2019, https://www.voaindonesia.com/a/iuran-bpjs-kesehatan-naik-100-persen-jokowi-rakyat-harusmengerti/5147296.html, accessed Januari 28, 2020. 
Parliament had held two meetings aimed at finding solutions, to make a substantial increase in the fee rates. ${ }^{2}$

The increase in the fee rates from the Health Insurance Provider institution was rejected by the poor. Chairperson of the Indonesian Poor People's Union, Wahida Baharuddin Upa stated that at this time the people do not want an increase in fees, but excellent service. According to Wahida Baharuddin Upa, a very significant increase in fees has the potential to violate the basic rights of citizens to obtain health services. In the constitution, it has been explained that health is a basic right of citizens which must not be impeded, including the issue of fee. ${ }^{3}$

In order to bind participants to the Government Health social Insurance Institution, the government creates administrative punishment to get public services for participants who are in arrears, such as Building Permits, Driving Licence, land certificates, passports, and Vehicle Number Certificates. Director of the Indonesian Consumer Legal Aid Institute, Firman Turmantara Endipradja stated that the Indonesian constitution mandates to the state to serve every citizen and population to fulfill their basic rights and needs within the framework of public services. The existence of administrative sanctions will make the state's main tasks violated by the government. ${ }^{4}$

The policy of applying administrative punishment for the arrears of the Health - Social Security Administering Institution is considered unfair and it violates the constitution. According to Firman, at least there are seven laws that will be violated, including Consumer Protection law, law of State Administrators that are Clean and Free from Corruption, Collusion and Nepotism, Law of Human Rights, National Social Security System law, Law of Public Services, Law of Social Security Administering institution, and Law of Government Administration. Firman added that the Indonesian constitution mandates that the state should serve every citizen to fulfill their basic needs and rights within the framework of public services. ${ }^{5}$

2 Iuran BPJS Kesehatan Naik, DPR: Pemerintah Abaikan keputusan Bersama, 03 januari 2020 , https://www.beritasatu.com/kesehatan/593631/iuran-bpjs-kesehatan-naik-dpr-pemerintah-abaikan-keputusanbersama, accessed Januari 28, 2020.

3 Kenaikan Iuran BPJS Kesehatan Melanggar Konstitusi, $06 \quad$ September 2019, http://www.katta.id/news/2019/09/06/1593/kenaikan-iuran-bpjs-kesehatan-melanggar-konstitusi, $\quad$ accessed January 28, 2020.

4 Rencana Sanksi bagi Penunggak Iuran BPJS Kesehatan Disebut Melanggar Konstitusi, 14 Oktober 2019, https://www.liputan6.com/health/read/4085614/rencana-sanksi-bagi-penunggak-iuran-bpjs-kesehatan-disebutmelanggar-konstitusi, accessed January 28, 2020.

5 HLKI Jabar: Sanksi Penunggak Iuran BPJS Kesehatan Tidak Adil dan Melanggar Konstitusi, 14 Oktober 2019,https://www.pikiran-rakyat.com/bandung-raya/pr-01321044/hlki-jabar-sanksi-penunggak-iuran-bpjskesehatan-tidak-adil-dan-melanggar-konstitusi, accessed January 28, 2020. 
Executive Director of Lokataru Foundation, Haris Azhar urged the Government to cancel the increase in the fee of the Health - Social Security institution before there is an evaluation related to the service of the Health - Social Security institution. According to Haris Azhar, the increasing fees, it violates constitution, Number 36 of 2009 concerning Health, Article 25 of the Universal Declaration of Human Rights, Article 9 of constitution, Number 11 of 2005 concerning Ratification of the International Covenant on Economic, Social and Cultural Rights, and Article 41 of constitution No. 39 of 1999 concerning Human Rights. ${ }^{6}$

Observing fee increased of the Health - Social Security Administering institution, an interesting critical question to analyze is, how about the regulation of health services, is there a right to health services, and what are the responsibilities of public health services in the Indonesian constitution? This article attempts to answer some of these questions.

Actually many research or conceptual articles have been done by previous researchers in the field of health law. However, most of their articles are about fulfilling the right to health for the community or articles on the right to health in the national health insurance program or articles on the conception of state responsibility in fulfilling the right to public health in the Indonesian constitution. So far there is no research or conceptual articles as a critical review of this issue of increasing health insurance contributions related to the Indonesian constitution which mandates to the State responsibility for public health services. Therefore, the different focus of the study shows that this article has novelty that has never been done by other researchers before.

\section{Methods}

Normative law design has been used as a method in this research. This research method was conducted by analyzing some materials of library research. ${ }^{7}$ Normative law research conducted a law analysis of some norms or doctrine to solve the law problem. ${ }^{8}$

This research also used a legislative approach and a conceptual approach. The legislative approach is carried out because the focus of this research was included from some of the applicable laws and regulations, while the conceptual approach was done because the focus of

\footnotetext{
6 HLKI Jabar: Sanksi Penunggak Iuran BPJS Kesehatan Tidak Adil dan Melanggar Konstitusi, 14 Oktober 2019,https:/www.pikiran-rakyat.com/bandung-raya/pr-01321044/hlki-jabar-sanksi-penunggak-iuran-bpjskesehatan-tidak-adil-dan-melanggar-konstitusi, accessed January 28, 2020.

7 Jonaedi Efendi and Johnny Ibrahim, Metode Penelitian Hukum: Normatif Dan Empiris (Jakarta: Prenada Media, 2018), 123.

8 Ibid.
} 
this research was included from some of the views in the science of law and the conception of law, that related to the problem being analyzed. Both of these approaches are important in order to be analyzed deeply, and also they were about the responsibilities of public health services in the Indonesian constitution.

\section{Results and Discussion}

\subsection{Health Services Regulation}

The issue of health services for the citizen of Indonesia has become a topic in the midst of domestic and overseas people. In overseas, health issues have been regulated in several rules. United Nations was established on December 10 of 1948, has authorized the Universal Declaration of Human Rights (UDHR) and included points, regarding health services in Article 25 paragraph (1) of UDHR, namely, "If each person has the right toward an adequate level of living for his health and his family's welfare, including the right to food, clothing, housing, as well as health care and community services needed". The right to health is a fundamental right whose realization is the responsibility of the state. ${ }^{9}$ Indonesia is one of the member countries of the United Nations which has a commitment to implement the declaration and strive to realize health services for the people in accordance with the country's capabilities. ${ }^{10}$

World Health Organization Constitution (WHO) was established on 7 April 7 1948, showed a hard attention toward health services for society, as stated in the preamble of the constitution of World Health Organization mentioned: "The enjoyment of the highest attainable standard of health is one of the basic rights for every human being without distinction of race, religion, political belief, economic or social conditions". The Constitution of WHO did not use the term of human rights, but fundamental rights. The use of the term fundamental rights showed that health services for people are a basic rights. ${ }^{11}$ Therefore, the right to health is a basic right for each individual that must be fulfilled in various countries. ${ }^{12}$

In its development, the United Nations General Assembly which convened on 16 December 1966, decided the guarantee of the right to health in the International Covenant on

\footnotetext{
9 Rico Mardiansyah, "Dinamika Politik Hukum Dalam Pemenuhan Hak Atas Kesehatan Di Indonesia," Jurnal Veritas Et Justitia 4, No. 1 (2018): 229.

10 Ibid., 242-243.

11 Alfionita Giovani Masau, "Pemenuhan Hak Pelayanan Kesehatan Bagi Masyarakat Di Rumah Sakit Lakipadada Kabupaten Tana Toraja,” Jurnal Phinisi Integration Review 2, No. 2 (2019): 175.

12 Lembaga Studi dan Advokasi Masyarakat, Kesehatan Sebagai Hak Asasi Manusia, https://refensi.elsam.or.id/wp-content/uploads/2014/12/KESEHATAN-SEBAGAI-HAK-ASASI-MANUSIA, accessed September 9, 2019.
} 
Economic, Social and Cultural Rights. Article 12 paragraph (1) of the Covenant states, "States parties to the convention recognize the right of everyone to enjoy the highest standards that can be achieved in matters of physical and mental health". The Covenant emphasized that each country is responsible for the physical and mental health services of its people. ${ }^{13}$

The Indonesian Constitution has mandated health services for the people of Indonesia. Article 28H Paragraph (1) and Article 34 Paragraph (2) and (3) of the 1945 Constitution of the Republic of Indonesia. Article 28H Paragraph (1) states, "Every person has the right to live in physical and spiritual prosperity, and living get a good and healthy environment and have the right to get health services ". Then, Article 34 paragraph (2) states, "The state improves the social security system for all people and empowers people who are weak and cannot be in accordance with human dignity". Furthermore, Article 34 paragraph (3) states, "The State is responsible for the provision of appropriate health services and public services".

Furthermore, constitution number 39 of 1999 concerning Human Rights which was recognized on September 23, 1999, requires health services for the people. Article 9 states, "Every person has the right to live, maintain life and improve his standard of living. Everyone has the right to live in peace, security, peace, happiness, prosperity, physically and mentally. Everyone has the right to a good and healthy environment. "

Constitution number 36 of 2009 concerning Health which was recognized on October 13, 2009, stated that the importance of health services for the people. Article 4 states, "Everyone has the right to health". Article 5 paragraph (1) states, Every person has the same right in gaining access to resources in the health sector. (2) Every person has the right to obtain safe, quality and affordable health services. (3) Every person has the right to independently and be responsible for determining for themselves the health services needed for him. While Article 6 states, "Everyone has the right to a healthy environment for achieving health status". So the right to healthy living and the right to get health services is a right that everyone has.

The Government and Parliament have agreed to develop a social security system by organized constitution Number 40, 2004 concerning the National Social Security System on October 19, 2004. This national social security program is a program that provides certainty for health protection and assistance for all people. ${ }^{14}$ To adjust the mandate of Law Number 40 of 2004, the Indonesian Parliament authorized constitution Number 24 of 2011 concerning the

13 Ibid

14 Endang Wahyati Yustina, "Hak Atas Kesehatan Dalam Program Jaminan Kesehatan Nasional Dan Corporate Social Responsibility (CSR),” Jurnal Kisi Hukum: Jurnal Ilmiah Hukum 14, No. 1 (2015): 108. 
Social Security Administering agency on November 25, 2011. The ratification of this law took the Indonesian state into a new era of national social security. ${ }^{15}$ The ratification of this law aims to realize the health status of Indonesian citizens. ${ }^{16}$

\subsection{The Right of Health Services}

Health services are important services to be provided or driven by the government, because health services are the basic services for the community with their unique nature. Improvement of health management from time to time must always be done in order to improve public health, prevent and repair various kinds of diseases suffered by individuals, families, or communities. ${ }^{17}$

Health services are everyone's basic needs. Health as an individual's right and the state has a responsibility for health. In the instrument, the right to health is regulated in various international and national instruments. In international instruments, the Right to Health is contained in Article 25 of the Universal Declaration of Human Rights, Article 12 of the International Covenant on Economic, Social and Cultural Rights, Article 12 of the Convention on the Elimination of All Forms of Discrimination against Women, and Article 24 of the Convention on the Rights of the Child. In the national instrument, the right to health is regulated in Article 28H paragraph (1) and Article 34 paragraph (3) of the 1945 Constitution of the Republic of Indonesia, Article 9 of the Law on Human Rights, and Article 12 of Law Number 11 of 2005 concerning Ratification of the Covenant Social, Economic and Cultural Rights, and the Law on Health. ${ }^{18}$

At some international conventions, the provisions regarding the right to health are stipulated as one of the fundamental rights possessed by every individual. Provisions on the right to health which are fundamental rights include the preamble of the World Health Organization Constitution which states, "The enjoyment of the highest attainable standard of health is one of the fundamental rights of every human being without distinction of race, religion, political belief, economic or social conditions. ${ }^{19}$ Then the general comment from the Committee on Economic,

15 Ahmad Nizar Shihab, "Hadirnya Negara Di Tengah Rakyatnya Pasca Lahirnya Undang-Undang Nomor 24 Tahun 2011 Tentang Badan Penyelenggara Jaminan Sosial (The Presence Of The State Among People After The Declaration Of Law Number 24 Year 2011 Concerning Social Security Administeri," Jurnal Legislasi Indonesia 9, No. 2 (2018): 175.

16 Endang Wahyati Yustina, Op. Cit., 1.

17 Amirul Mustofa, at. al., Administrasi Pelayanan Kesehatan Masyarakat, (Surabaya: Jakad Media, 2020$), 53$.

18 KontraS, JKN, Hak Atas kesehatan dan Kewajiban Negara, Bulletin 15 Mei 2017, https://kontras.org/2017/05/15/jkn-hak-atas-kesehatan-dan-kewajiban-negara/, accessed January 29, 2020.

19 Virginia A. Leary, The Right to Health in International Human Right Law, Health and Human Right, The President and Fellows of Harvard Colleg 1, No.1: 32. 
Social and Cultural Rights on the right to health stated that Health is a fundamental human right that is indispensable for the exercise of other human rights. These general comments place the right to health as a fundamental and invaluable human right for the implementation of other human rights. As a fundamental right that must be fulfilled by the state, the right to health has the same status as other fundamental rights, even though the right to health is not yet widely recognized as a human right. $^{20}$

Health services have indeed become the attention of the Indonesian state. Article 34 paragraph (3) of the 1945 Constitution of the Republic of Indonesia states that the State is responsible for the provision of adequate health service facilities and public service facilities. This provision explains that the state is not only responsible for providing modest health facilities, but health facilities with certain standards deemed appropriate. Article 22 paragraph (1) of the Law on the National Social Security System which states that health insurance is a personal service in the form of health services that include promotive, preventive, curative and rehabilitative services, including medicines and consumable medical materials that are needed. ${ }^{21}$ Health services are not only related to individual services but also related to promotive, preventive, curative and rehabilitative services. The constitution on the National Social Security System aims to guarantee access to health services. ${ }^{22}$

The government is responsible for regulating the healthy living standard for all Indonesian people. ${ }^{23}$ The constitution on Health makes it clear that individuals, families, and communities get the protection of their right to health. To apply the fulfillment of the right to health, the government must provide health services that are equitable, equitable, and accessible to all the people of Indonesia. Therefore, the government must make several efforts to ensure access to health services for all Indonesian citizens. ${ }^{24}$ Furthermore, the constitution on the National Social Security System and the constitution on the Provider of Social Security are a legal basis for applying the protection of the right to health of all citizens so that their basic needs can be fulfilled properly and fairly. ${ }^{25}$

20 Rico Mardiansyah, Op. Cit., 228.

21 Fheriyal Sri Isriawaty, "Tanggung Jawab Negara Dalam Pemenuhan Hak Atas Kesehatan Masyarakat Berdasarkan Undang Undang Dasar Negara Republik Indonesia Tahun 1945," Jurnal Ilmu Hukum Legal Opinion 3, No. 2 (2015): 2.

22 Ibid., 3.

23 Budi Setiyono, "Perlunya Revitalisasi Kebijakan Jaminan Kesehatan Di Indonesia,” Jurnal Ilmu Politik 9 , No. 2 (2018): 40.

24 Fheriyal Sri Isriawaty, Op. Cit., 2.

25 Yuwinda Ardila, "Keadilan Sosial bagi Pasien Pengguna BPJS dalam Memperoleh Layanan Kesehatan (Perspektif Konseling Multikultural)," Jurnal Kajian Konseling dan Pendidikan 1, No. 3 (2018): 74. 
The constitution on Health specifies several articles concerning the right to health. Article 4 states that everyone has the right to health. The right to health means the right to obtain health care facilities in order to apply the highest degree of health. Article 5 paragraph (1) states that everyone has the same rights in gaining access to resources in the health sector, then paragraph (2) states that everyone has the right to obtain safe, quality and affordable health services, while paragraph (3) states that each person has the right to independently and is responsible for determining the health services required for themselves. The provisions of Article 6 state that everyone has the right to a healthy environment for the achievement of health status. So the right to get health services is a right that everyone has. ${ }^{26}$

\subsection{Responsibility of Public Health Service Based on the Constitution of Indonesian}

Amendments 1945 Constitution of the Republic of Indonesia has mandated health services for the people of Indonesia in Article 28H paragraph (1), Article 34 paragraph (2) and (3). These articles regulate the right to health and the responsibility of the state to apply the right to health. Refusal to apply the right to public health is a violation of the Constitution 1945 of the Republic of Indonesia. ${ }^{27}$ Therefore, it is very important that there is a commitment from the government to apply the right to health.

Health is the basis for recognizing humanity. An unhealthy individual automatically reduces his right to life. He cannot use his right to work, his right to express his opinion, his right to education, and so on. ${ }^{28}$ Health is a fundamental right of every human being, while the government is obliged to apply the people's interest so that the right to healthy living can be fulfilled. ${ }^{29}$ The right to health must be realized based on the ideals of the people listed in the Pancasila and Constitution 1945 of the Republic of Indonesia. ${ }^{30}$ For this reason, legal support is needed to apply the Indonesian people's health.

Applying to provide health services to the people is the state responsibility. The government should prepare a health budget to ensure the health of every Indonesian

Endang Wahyati Yustina, Op. Cit., 4.

Majda El Muhtaj, Dimensi-Dimensi HAM: Mengurai Hak Ekonomi, Sosial, dan Budaya (Jakarta: Rajawali Pers, 2008): 152.

28 Lembaga Studi dan Advokasi Masyarakat, Loc. Cit.

29 Fheriyal Sri Isriawaty, Op. Cit., 7.

30 Rif'atul Hidayat, "Hak Atas Derajat Pelayanan Kesehatan Yang Optimal," Jurnal Hukum dan Pemikiran 16, No. 2 (2016): 127. 
citizen. ${ }^{31}$ Because health is a valuable thing that people needed. Therefore, the national social security system should have a purpose to protect people for sure. ${ }^{32}$

The government is trying to protect the people by creating a national social security model in the health sector and improving the quality of health of the people of Indonesia. However, the implementation of social health insurance for public health is still carried out partially, which makes the poor have not been able to enjoy social health insurance as they should. ${ }^{33}$

The application of this kind of state responsibility for public health services began in 2000 . The government designed an integrated national health insurance model. In 2004, senator authorized health insurance based on the National Social Security System Act. This constitution applied the state machine to provide social assistance for the poor so that all people become participants in the national health insurance with the principle of compulsory insurance. The concept of national health insurance was applied seven years later after authorized the Social Security Organizing Agency Act. ${ }^{34}$ The principle of mandatory insurance carried the implications of the state's obligation to apply the right to public health services into the people's obligation to follow the health insurance participant to apply the right to health services.

Initially, the concept of the right to health was separated from the national social security system. Furthermore, the concept of the right toward health merges in the concept of health insurance. The concept of the right to health applied a social health insurance system to all people. The President and the Indonesian Parliament agreed to merge social health insurance into the national social security system. ${ }^{35}$ Both state institutions agreed to make a concept change without considering the possibility of not fulfilling the right to health of the Indonesian people.

The government's policy to develop a social security system should be based on laws and regulations directed at the social protection system. The constitution of the National Social Security System devised a coordinated and integrated social security model. This constitution is characterized by the fact that every Indonesian citizen is required to be a participant and provide contribution assistance for everyone who is poor. Even though the poor who are unable to pay fees will still get social security because the government provides subsidy contributions for the

\footnotetext{
31 Abu Huraerah, "Perlindungan Sosial Bidang Kesehatan Bagi Masyarakat Miskin," Jurnal Ilmu Kesejahteraan Sosial 14, No. 2 (2015): 72.

32 Yuwinda Ardila, Loc. Cit.

33 Rudy Hendra Pakpahan and Eka N.A.M. Sihombing, "Tanggung Jawab Negara Dalam Pelaksanaan Jaminan Sosial Responsibility State In The Implementation Of Sosial Security," Jurnal Legislasi Indonesia 9, No. 2 (2018): 163-74.

34 Budi Setiyono, Op. Cit., 45-46.

35 Rico Mardiansyah, Op. Cit., 241-242.
} 
poor. $^{36}$ This model can create problems when the government did not have data of the poor that must be given retribution subsidized.

The constitution of National Social Security System has the concept of the payment of mandatory fee every month to all citizens, both rich and poor. The payment of fee is a form of transfer of state responsibility to the people regarding national health insurance. ${ }^{37}$ The payment of mandatory fee is a wrong concept because of two reasons. First, the payment of mandatory fee has let go of the state's responsibility in the health sector. Second, the payment of mandatory fee has forced people to become participants in health insurance.

In another section, the constitution of the Social Security Organizing Institution acts as an insurance company. The social security model implemented throughout Indonesia is based on the principle of equity and social insurance. The Social Security Administration Institution has the right to collect, manage funds and impose sanctions on participants who do not pay fee. In addition, the Social Security Administration Institution has the authority to manage social security funds for the purpose of investing capital. ${ }^{38}$ This concept showed the strong influence of neo-liberalism in the formation of law in Indonesia.

In fact, the national social security system which is based on the payment of mandatory fee has been sued by its constitutionality. Because payment of mandatory fee for all people to obtain social security was criticized for having violated the constitutional rights of the Indonesian people. People who object to the social insurance model could submit a material test of the Law on the National Social Security System to the Constitutional Court. Social security providers have exploited the people with the obligation to pay social security fee. Social security programs have changed the meaning of social security with social insurance. ${ }^{39}$ The two concepts are clearly different. Social security is the protection of the state for its people to realize the needs of a decent life. While social insurance is insurance formed by the government to serve social security for every citizen.

The role as an insurance company began to be implemented after the enactment of Law Number 24 Year 2011. The Social Security Organizing Insttitution carries out the payment of fee

\footnotetext{
36 Muh Kadarisman, “Analisis tentang Pelaksanaan Sistem, Sistem Jaminan Sosial Kesehatan Pasca Putusan Mahkamah Konstitusi No. 07/PUU-III/2005," Jurnal Hukum Ius Quia Iustum 22, No. 3 (2015): 475.

37 Endang Sutiah Pane, SJSN dan BPJS, Memalak Rakyat Atas Nama Jaminan Sosial, 1 Januari 2014, https:lintasgayo.co/2014/01/01/sjsn-dan-bpjs-memalak-rakyat-atas-nama-jaminan-sosial, accessed September 13 2019.

38 Ibid.

39 Alfitri, "Ideologi Welfare State Dalam Dasar Negara Indonesia: Analisis Putusan Mahkamah Konstitusi Terkait Sistem Jaminan Sosial Nasional,” Jurnal Konstitusi 9, No. 3 (2012): 453.
} 
and provides sanctions to participants who pay social security contributions. Many people object to the payment of social social security fee, even though the Social Security Administration Institution makes the payment of fee is not too expensive. According to Max Boli Sabon, the enactment of Law Number 24 Year 2011 shows that the government has not fully implemented the citizens constitutional rights in the field of health insurance. The implementation of social security should not be profit oriented. ${ }^{40}$

Nine years later, President Joko Widodo enacted Presidential Regulation Number 75 of 2019 which contained a 100 percent increase in social health insurance fees as of January 1 of 2020. Although the government had raised health insurance fees, the people still hoped for government policies to cancel the fee increase. The reason, the Indonesian constitution has made it clear that the state is responsible for providing health services to the people.

Community Dialysis Patients object to the enactment of the Presidential Regulation, then they submit a judicial review of Presidential Regulation Number 75 of 2019 to the Supreme Court. On 27 February 2020, the Supreme Court Judge Panel canceled the increase in health social security fee. The Supreme Court stated that Presidential Regulation Number 75 of 2019 had no legal force and several articles contradicted Article 34 paragraph (1) and (2), Article 23A, Article $28 \mathrm{H}$, and Article 34 of the 1945 Constitution. In addition, Presidential Regulation contrary to Article 2, Article 4 letters b, c, d, and e, Article 17 paragraph (3) of Law Number 40 Year 2004, Article 2, Article 3, Article 4 letters b, c, d, and e of Law Law Number 24 of 2011, and Article 4, Article 5 paragraph (2), and Article 171 of Law Number 36 of $2009 .^{41}$

If examined intensively, the decision of the Supreme Court judges who cancel the increase in health insurance social security is appropriate. Because health care is a basic need for the people that must be met by the state. And also, currently the poor and economically disadvantaged people need health services. They do not want an increase in health social security fees, but they want adequate health services.

In addition, the decision of the Supreme Court judges regarding the amount of health social security contributions returned to Presidential Regulation Number 28 of 2018 is also appropriate, because Presidential Regulation Number 75 of 2019 which contains an increase in health social

\footnotetext{
40 Sejumlah Tokoh Kritik Konsep Jaminan Sosial, Selasa 21 Mei 2013, https://www.hukumonline.com/berita/baca/lt519abc859ef5a/sejumlah-tokoh-kritik-konsep-jaminan-sosia, accessed September 13, 2019.

41 Iuran Batal Naik, BPJS Kesehatan Tunggu Salinan Putusan MA, Selasa, 10 Maret 2020, https://www.cnnindonesia.com/ekonomi/20200310104944-83-482016/iuran-batal-naik-bpjs-kesehatan-tunggusalinan-putusan-ma, diakses pada tanggal 12 April 2020.
} 
security contributions has violated the basic rights of citizens to obtain health services. The enforcement of Presidential Regulation Number 75 Year 2019 contradicts the 1945 Constitution of the Republic of Indonesia and several laws and regulations, such as Law Number 40 of 2004, Law Number 24 of 2011, and Law Number 36 of 2009.

The government should not have made a policy of increasing health social security fee. The government must not neglect the responsibilities of public health services and hand over the burden of responsibility for health services to the people. The government should be responsible for providing health services to every citizen that should not be ignored, including the issue of healthcare costs. Moreover, the Indonesian constitution expressly states that the people have the right to receive health services, otherwise the state is responsible for providing health services to the people.

Discussion on the responsibilities of health services is a serious issue. The state is responsible for the realization of public health services which are guaranteed by the international human rights. If there are countries that do not carry out their responsibilities, the country is considered to have violated human rights or international law. If there are countries that do not carry out their responsibilities in the field of public health services, then the burden of responsibility will be taken over by the international community. ${ }^{42}$ Therefore, the government should be responsible for providing health services to the people. If the government does not fulfill its obligation to provide health services to the people, then it can be categorized as a form of violation of human rights both at the level of implementation and omission. ${ }^{43}$

After the amendments to several articles in the Indonesian constitution, the government is obliged to provide public health services as a fundamental part of people's development which must spread throughout Indonesia. Therefore, the government should prepare a larger budget for the health sector to further encourage the health insurance model for every Indonesian citizen.

\section{Conclusions}

Health services for the people are regulated in several international and national rules. The international rules are regulated in Article 25 of the Universal Declaration of Human Rights, the preamble of the World Health Organization Constitution, and Article 12 paragraph (1) of the

42 Firdaus, "Pemenuhan Hak Atas Kesehatan Bagi Penyandang Skizofrenia di Daerah Istimewa Yogyakarta," Jurnal Ilmiah Kebijakan Hukum 10, No. 1 (2016): 94.

43 Eka Ryanda Pratiwi, at. al., "Perlindungan Hukum Terhadap Hak Asasi Pasien Pengguna Badan Penyelengara Jaminan Sosial Kelas 3," Syiah Kuala Law Journal 1, No. 1 (2017): 122. 
International Covenant on Economic, Social and Cultural Rights. While the national rules are regulated in Article 28H paragraph (1) and Article 34 paragraph (2) and (3) Constitution of the Republic of Indonesia 1945, Article 9 of Law Number 39 of 1999 concerning Human Rights, Article 4, Article 5 and Article 6 of Law Number 36 of 2009 concerning Health, Law Number 40 of 2004 concerning the National Social Security System, and Law Number 24 of 2011 concerning Social Security Organizing institution.

Health services are everyone's basic needs. Health as an individual's right and the state, they have a responsibility for health. Health services are a concern of the Indonesian state. The government is responsible to organize the healthy living standard for all Indonesian people. There are four things that must be obeyed by the state in fulfilling the right to health, such as availability, accessibility, quality, and equality. Availability requires the availability of a number of health services, such as hospital facilities, medicines, health workers, and health financing. Accessibility requires that health services are affordable both economically and geographically for everyone and respectful of the culture of the community. Quality requires health services to meet the appropriate standards. Then, equality requires health services that can be accessed equally by everyone.

The Indonesian Constitution has entrusted health services for the people of Indonesia. Refusal to realize the right to public health is a violation of the Indonesian constitution. The state is responsible for providing health services to the people, so the government should prepare a health budget to ensure the health of every Indonesian citizen. Because it is a valuable thing as expected by everyone. Therefore, the national social security system should aim to protect the people. The people have the right to get health services, whereas the state is responsible for providing health services. Even though the government raises retribution, people expect the government to cancel the fee increas, due to the fact that the Indonesian constitution has made it clear that the state is responsible for providing health services to the people.

\section{References}

Alfitri. "Welfare State Dalam Dasar Negara Indonesia: Analisis Putusan Mahkamah Konstitusi Terkait Sistem Jaminan Sosial Nasional.” Jurnal Konstitusi 9, No. 3 (2012): 452.

Ardila, Yuwinda. "Keadilan Sosial Bagi Pasien Pengguna BPJS Dalam Memperoleh Layanan Kesehatan (Perspektif Konseling Multikultural)." Jurnal Kajian Konseling Dan Pendidikan 1, No. 3 (2018). 
Huraerah, Abu. "Perlindungan Sosial Bidang Kesehatan Bagi Masyarakat Miskin.” Jurnal Ilmu Kesejahteraan Sosial 14, No. 2 (2015): 72.

Efendi, Jonaedi and Ibrahim Johnny. Metode Penelitian Hukum: Normatif Dan Empiris. Jakarta: Prenada Media, 2018.

El-Muhtaj, Majda. Dimensi-Dimensi HAM: Mengurai Hak Ekonomi, Sosial, Dan Budaya. Rajawali Press, RajaGrafindo Persada, 2008.

Firdaus. "Pemenuhan Hak Atas Kesehatan Bagi Penyandang Skizofrenia di Daerah Istimewa Yogyakarta." Jurnal Ilmiah Kebijakan Hukum 10, No. 1 (2016): 94.

Giovani Masau, Alfionita. "Pemenuhan Hak Pelayanan Kesehatan Bagi Masyarakat Di Rumah Sakit Lakipadada Kabupaten Tana Toraja.” Jurnal Phinisi Integration Review 2, No. 2 (2019): 175.

Hidayat, Rif'atul. "Hak Atas Derajat Pelayanan Kesehatan Yang Optimal.” Syariah: Jurnal Hukum Dan Pemikiran 16, No. 2 (2017): 127-34.

Iman. "Naikan Iuran BPJS Kesehatan, Pemerintah Dituding Langgar UU Kesehatan.” RRI.co.id, 2019

.http://rri.co.id/post/berita/744260/info_publik/naikan_iuran_bpjs_kesehatan_pemerintah_d ituding_langgar_uu_kesehatan.html.

Intan, Ghita. "Iuran BPJS Kesehatan Naik 1000 Persen, Jokowi Minta Rakyat Mengerti, 31 Oktober 2019.” VOA Indonesia, 2019. https://www.voaindonesia.com/a/iuran-bpjskesehatan-naik-100-persen-jokowi-rakyat-harus-mengerti/5147296.html.

Isriawaty, Fheriyal Sri. "Tanggung Jawab Negara Dalam Pemenuhan Hak Atas Kesehatan Masyarakat Berdasarkan Undang Undang Dasar Negara Republik Indonesia Tahun 1945.” Jurnal Ilmu Hukum Legal Opinion 3, No. 2 (2015).

Kadarisman, Muh. “Analisis Tentang Pelaksanaan Sistem Jaminan Sosial Kesehatan Pasca Putusan Mahkamah Konstitusi No. 07/PUU-III/2005.” Jurnal Hukum Ius Quia Iustum 22, No. 3 (2015): 467-88.

"KontraS, JKN, Hak Atas Kesehatan Dan Kewajiban Negara, Bulletin 15 Mei 2017.” kontras, 2017.

Leary, Virginia A. "The Right to Health in International Human Rights Law." Health and Human Rights, The President and Fellows of Harvard College 1, No.1: 32.

Lellolsima, Samrut. “Kenaikan Iuran BPJS Kesehatan Melanggar Konstitusi.” Katta.id, 2019. http://www.katta.id/news/2019/09/06/1593/kenaikan-iuran-bpjs-kesehatan-melanggar- 
konstitusi.

“Lembaga Studi Dan Advokasi Masyarakat, Kesehatan Sebagai Hak Asasi Manusia.” Accessed September 29, 2019. https://refensi.elsam.or.id/wpcontent/uploads/2014/12/KESEHATAN-SEBAGAI-HAK-ASASI-MANUSIA.

Mardiansyah, Rico. "Dinamika Politik Hukum Dalam Pemenuhan Hak Atas Kesehatan Di Indonesia.” Jurnal Veritas Et Justitia 4, No. 1 (2018).

Masau, Alfionita Giovani. "Pemenuhan Hak Pelayanan Kesehatan Bagi Masyarakat Di Rumah Sakit Lakipadada Kabupaten Tana Toraja.” Phinisi Integration Review 2, no. 2 (2019): $174-84$.

Mustofa, Amirul, at. al. Administrasi Pelayanan Kesehatan Masyarakat. Surabaya: Jakad Media, 2020.

Nugraha, Arie. "Rencana Sanksi Bagi Penunggak Iuran BPJS Kesehatan Disebut Melanggar Konstitusi, $\quad 14 \quad$ Oktober 2019.” $\quad 2019$. https://www.liputan6.com/health/read/4085614/rencana-sanksi-bagi-penunggak-iuranbpjs-kesehatan-disebut-melanggar-konstitusi.

Pane, Endang Sutiah. "SJSN Dan BPJS, Memalak Rakyat Atas Nama Jaminan Sosial,” 2014. https://lintasgayo.co/2014/01/01/sjsn-dan-bpjs-memalak-rakyat-atas-nama-jaminan-sosial.

Pakpahan, Rudy Hendra and Sihombing, Eka N.A.M. "Tanggung Jawab Negara Dalam Pelaksanaan Jaminan Sosial Responsibility State In The Implementation Of Sosial Security.” Jurnal Legislasi Indonesia 9, No. 2 (2018): 163-74.

Pratiwi, Eka Ryanda, at. al. "Perlindungan Hukum Terhadap Hak Asasi Pasien Pengguna Badan Penyelengara Jaminan Sosial Kelas 3.” Syiah Kuala Law Journal 1, No. 1 (2017): 122.

Rachmawati, Ai Rika. "HLKI Jabar: Sanksi Penunggak Iuran BPJS Kesehatan Tidak Adil Dan Melanggar Konstitusi.” pikiran rakyat, 2019. https://www.pikiran-rakyat.com/bandungraya/pr-01321044/hlki-jabar-sanksi-penunggak-iuran-bpjs-kesehatan-tidak-adil-danmelanggar-konstitusi.

Shihab, Ahmad Nizar Shihab. "Hadirnya Negara Di Tengah Rakyatnya Pasca Lahirnya UndangUndang Nomor 24 Tahun 2011 Tentang Badan Penyelenggara Jaminan Sosial (The Presence Of The State Among People After The Declaration Of Law Number 24 Year 2011 Concerning Social Security Administeri.” Jurnal Legislasi Indonesia 9, No. 2 (2018): 175.

"Sejumlah Tokoh Kritik Konsep Jaminan 2013. 
https://www.hukumonline.com/berita/baca/lt519abc859ef5a/sejumlah-tokoh-kritik-konsepjaminan-sosia.

Setiyono, Budi. "Perlunya Revitalisasi Kebijakan Jaminan Kesehatan Di Indonesia.” Jurnal Ilmu Politik 9, No. 2 (2018).

Yustina, Endang Wahyati. "Hak Atas Kesehatan Dalam Program Jaminan Kesehatan Nasional Dan Corporate Social Responsibility (Csr).” Jurnal Kisi Hukum 14, No. 1 (2015). 